\title{
The Impact of Far-Red Light Supplementation on Hormonal Responses to Cold Acclimation in Barley
}

\author{
Mohamed Ahres ${ }^{1,2}$, Tamás Pálmai ${ }^{1} \mathbb{D}$, Krisztián Gierczik ${ }^{1}$, Petre Dobrev ${ }^{3} \mathbb{D}, \operatorname{Radomíra~Vanková~}^{3, *(\mathbb{D})}$ \\ and Gábor Galiba 1,2 \\ 1 Centre for Agricultural Research, Agricultural Institute, Eötvös Loránd Research Network, \\ H-2462 Martonvásár, Hungary; mohamed.ahres@atk.hu (M.A.); palmai.tamas@atk.hu (T.P.); \\ gierczik@gmail.com (K.G.); galiba.gabor@atk.hu (G.G.) \\ 2 Department of Environmental Sustainability, Festetics Doctoral School, IES, Hungarian University of \\ Agriculture and Life Sciences, H-8360 Keszthely, Hungary \\ 3 Institute of Experimental Botany of the Czech Academy of Sciences, 16502 Prague, Czech Republic; \\ dobrev@ueb.cas.cz \\ * Correspondence: vankova@ueb.cas.cz
}

check for updates

Citation: Ahres, M.; Pálmai, T.; Gierczik, K.; Dobrev, P.; Vanková, R.; Galiba, G. The Impact of Far-Red Light Supplementation on Hormonal Responses to Cold Acclimation in Barley. Biomolecules 2021, 11, 450. https://doi.org/10.3390/biom11030450

Academic Editor: Guzel Kudoyarova

Received: 11 January 2021

Accepted: 16 March 2021

Published: 17 March 2021

Publisher's Note: MDPI stays neutral with regard to jurisdictional claims in published maps and institutional affiliations.

Copyright: (c) 2021 by the authors. Licensee MDPI, Basel, Switzerland. This article is an open access article distributed under the terms and conditions of the Creative Commons Attribution (CC BY) license (https:// creativecommons.org/licenses/by/ $4.0 /)$.

\begin{abstract}
Cold acclimation, the necessary prerequisite for promotion of freezing tolerance, is affected by both low temperature and enhanced far-red/red light (FR/R) ratio. The impact of FR supplementation to white light, created by artificial LED light sources, on the hormone levels, metabolism, and expression of the key hormone metabolism-related genes was determined in winter barley at moderate $\left(15^{\circ} \mathrm{C}\right)$ and low $\left(5^{\circ} \mathrm{C}\right)$ temperature. FR-enhanced freezing tolerance at $15^{\circ} \mathrm{C}$ was associated with promotion of abscisic acid (ABA) levels, and accompanied by a moderate increase in indole-3-acetic acid (IAA) and cis-zeatin levels. The most prominent impact on the plants' freezing tolerance was found after FR pre-treatment at $15^{\circ} \mathrm{C}$ (for 10 days) followed by cold treatment at FR supplementation (7 days). The response of ABA was diminished in comparison with white light treatment, probably due to the elevation of stress tolerance during FR pre-treatment. Jasmonic acid (JA) and salicylic acid (SA) were transiently reduced. When the plants were exposed directly to a combination of cold $\left(5^{\circ} \mathrm{C}\right)$ and FR supplementation, ABA increase was higher than in white light, and was associated with enhanced elevation of JA and, in the longer term (after 7 days), with IAA and cis-zeatin increase, which indicates a stronger stress response and better acclimation. Cold hardening was more efficient when FR light was applied in the early developmental stage of the barley plants (three-leaf stage, 18 days), rather than in later stages (28-days). The dynamics of the phytohormone changes are well supported by the expression profiles of the key hormone metabolism-related genes. This series of treatments serves as evidence for the close relationship between plant hormones, light quality, and low temperature at the beginning of cold acclimation. Besides the timing of the FR treatments, plant age also represents a key factor during light spectrum-dependent cold acclimation.
\end{abstract}

Keywords: phytohormones; frost-tolerance; low R/FR ratio; LED lighting; barley

\section{Introduction}

The ability of plant species to acclimate to cold and to develop frost tolerance is a genetically determined physiological trait. This adaptation process, the so-called "coldhardening" takes a relatively long time for overwintering plants in the temperate climate zone. In autumn, environmental changes (e.g., temperature, light intensity, and spectra) are required for cereals to prepare physiologically for winter frost. In the regulation of plant interactions with the altering environment, phytohormones have a pivotal role in controlling the coordination of the acclimation processes [1-4].

Based on their response to stress conditions, phytohormones can be divided into two groups. The first group consists of the so called "positive growth regulators" and includes auxins, cytokinins (CKs), gibberellins (GA), and brassinosteroids. The second 
group encompasses stress hormones with abscisic acid (ABA), jasmonic acid (JA), salicylic acid (SA), ethylene, and strigolactones [5].

One of the most important hormones in the responses to abiotic stresses is ABA, which is usually referred to as "the main abiotic stress hormone". It has a pivotal role in the response to drought, salinity, and also to cold stress [6]. To avoid cold injury, the elevation of ABA content can stabilize plant water homeostasis in the early stages of the cold stress response and stimulate the production of protective compounds [7]. For example, in einkorn wheat (Triticum monococcum ssp. monococcum (L.)) the up-regulation of ABA was detected in crowns and leaves on the first day at $4{ }^{\circ} \mathrm{C}$. This elevation promoted improvement of the plant water status via stomata closure, and promoted defense by stimulation of the expression of late embryogenesis abundant proteins (LEA proteins) [8]. In higher plants the starting point of the ABA biosynthesis pathway is the epoxidation of zeaxanthin and antheraxanthin to violaxanthin, which is catalyzed by a zeaxanthin epoxidase (ZEP) [9]. After the epoxidation, all-trans-violaxanthin is converted to 9-cisviolaxanthin or 9-cis-neoxanthin [10]. The next, rate-limiting step is the oxidative cleavage of 9-cis-violaxanthin and 9-cis-neoxanthin to xanthoxin catalyzed by 9-cis-epoxycarotenoid dioxygenase (NCED) [11-13]. The NCED genes seem to be very important in the cold adaptation process. In fact, in cold-treated wheat varieties the transcript level of NCED1 was down-regulated in leaves in the freezing-sensitive variety, whereas it was highly elevated in the freezing-tolerant genotype [14]. After oxidative cleavage, xanthoxin is transported from the plastids to the cytosol and converted to abscisic aldehyde by shortchain dehydrogenase (SDR) $[15,16]$. In the final step, abscisic aldehyde is oxidized to ABA by aldehyde oxidase (AO) [17].

SA has been reported to play an important role in both biotic and abiotic stress responses in a wide range of plant species. In cereals, numerous studies have shown that SA treatment has a positive effect on low temperature tolerance [18]. In barley, exogenous SA application improved cold tolerance by decreasing lipid peroxidation, as well as ice nucleation, in both cold-tolerant and -sensitive varieties. SA also influenced the activities of apoplastic antioxidant enzymes $[19,20]$. Pre-treatment with SA at normal growth temperature induced similar defense mechanisms in maize as cold, namely increased antioxidant activity [21]. In addition, SA can also protect plants from oxidative stress by balancing their redox state [22,23]. The main SA biosynthesis pathway includes conversion of phenylalanine by phenylalanine ammonia lyase (PAL), the parallel pathway is catalysed by isochorismate synthase (ICS) [24,25]. PAL was found to be a stress-inducible enzyme up-regulated by UV irradiation, high light intensity, or low temperature [26]. In cucumber, stimulation of PAL expression correlated with reduced photo- and oxidative damages during cold stress [27]. In cereals, the results seem to be ambiguous. One study reported up-regulation of $P A L$ in winter wheat during the whole cold-hardening period $\left(2^{\circ} \mathrm{C}\right.$ for 28 days) [28], whereas another study on winter wheat showed a decrease of PAL activity during cold treatment [29].

JA is involved in the regulation of many physiological processes and has a crucial role in many biotic and abiotic stress responses [30,31]. Transcription of many JA biosynthetic genes, as well as JA content, was reported to increase during cold stress, e.g., in rice [32]. An elevated JA level was also observed upon prolonged cold exposure in winter and spring wheat varieties [5]. Similarly, JA content elevation was described upon drought stress [33]. The JA biosynthetic pathway starts with phospholipid release from plastid membrane lipids, followed by lipoxygenase (LOXs) and $\alpha$-dioxygenase ( $\alpha$-DOXs) catalysis $[34,35]$. A potential role for LOX enzymes in cold acclimation was suggested in different plant species. However, freezing temperature treatment $\left(-10^{\circ} \mathrm{C}\right)$ led to great reduction of LOX activity in chickpea [36]. Prolonged heat or cold stress exposure led to significant changes in LOX-related volatile production in tomato [37].

Auxins are one of the most studied hormones in the field of plant growth and development, but very limited information is available about their role in cold acclimation. Most of the knowledge about the involvement of auxins in cold acclimation has been 
accumulated from Arabidopsis thaliana (L.) Heynh and rice studies [38-40]. The most biologically active auxin is indole-3-acetic acid (IAA) [41,42]. In general, prolonged cold stress positively influenced the accumulation of IAA, as well as the expression of many genes involved in auxin metabolism [5,32]. IAA can be synthesized by several pathways. One of the most important of these includes formation of indole-3-pyruvate (IPA) via the flavin monooxygenase (YUCCA) family, which is responsible for the decarboxylation of IPA into IAA [43].

The primary physiological functions of CKs are related to plant developmental processes (namely stimulation of cell division and enlargement), but they are also known to play a role in abiotic and biotic stress responses [44]. CKs were found to play a prominent role in cold protection [45] but their specific function in this area has not been fully elucidated yet. Usually, the amount of active CKs decreases immediately upon cold shock, which is related to the plant's effort to relocate the energy from growth to defense $[8,46]$. There are four active CK forms in plants, namely trans-zeatin (tZ), cis-zeatin (cZ), isopentenyladenine (iP), and dihydrozeatin (DHZ) [47]. The physiologically most active CK in stimulation of cell division is $\mathrm{tZ}$ [48], whereas the less active $\mathrm{cZ}$ displays other CK functions, and can be linked to stress responses [47,49]. The key, rate-limiting CK biosynthesis genes are the isopentenyltransferases (IPTs). The main degradation enzymes are cytokinin oxidase/dehydrogenases (CKXs).

In spite of the fact that many studies have dealt with interactions between lightinduced plant regulations and multiple hormonal pathways [50,51], little is known about hormonal changes due to the modifications of light quality during the cold acclimation processes. The most studied issue related to the effect of light spectrum composition is the "shade avoidance syndrome". Plants can use light spectrum composition as information on the neighbouring vegetation [52]. Blue and red light are used for photosynthesis, thus their decreased ratio in proportion to far-red light (FR) in a dense canopy (given by absorption of red light (R) by the neighbouring plants and their reflection of FR) represents an important morphological signal. The elevated proportion of FR initiates the shade avoidance response via a number of molecular mechanisms, including up-regulation of auxins [50,53]. Decreased R/FR ratios associated with IAA elevation resulted in the upregulation of cytokinin oxidase/dehydrogenase 6 (CKX6) in young plant leaves, which led to CK down-regulation and suppression of leaf growth [54,55]. The decreased R/FR ratio also negatively influenced the accumulation of JA and SA, which was associated with enhanced plant vulnerability to pathogen attack $[56,57]$.

However, apart from the shade effect, light-quality signals provide important seasonal information to plants as well. The effects of photoperiod on plant freezing tolerance and development are well established, whereas the possible influence of qualitative diurnal changes in the light environment has received less attention. The R/FR ratio is constant during daylight and independent of cloud cover but is much reduced during twilight, when solar elevation is less than $10^{0}$ [58]. Moving away from the equator, this phenomenon becomes more pronounced and characteristic of the temperate and boreal climates in the northern hemisphere. A reduced R/FR ratio during the twilight hours, especially in the evening, has been shown to control the cessation of internode elongation of aspen at the end of the active growing period, moreover twilight FR treatment advanced the leaf bud burst of silver birch $[59,60]$.

Light quality, especially higher FR proportion was found to be an important factor in cold acclimation processes in Arabidopsis thaliana (L.). In our previous studies, we demonstrated that the decreased R/FR ratio positively influenced the freezing tolerance of wheat and barley cereals, which could be further enhanced by increasing the light intensity in the pre-hardening phase $[61,62]$. Light is perceived by plants via photoreceptors; $\mathrm{R}$ and FR by phytochromes [61,63-65]. The fact that the most abundant phytochrome, PhyB, functions as a thermosensor [66], indicates that the combination of high FR and low temperature represents for plants a unique environmental signal, differing, at least partially, from the shade avoidance response at optimal temperature. This conclusion is supported 
by specific transcription profiles, e.g., the synergistic effect of FR-stimulated PhyA and low temperature on the expression of the key cold-induced transcription factors, CBFs [67].

Both low temperature and light quality substantially influence the metabolism of many phytohormones, which subsequently affects the cold acclimation processes in plants. The aim of the present study was the elucidation of the mode of action of FR (applied by artificial LED light sources) at moderate and low temperature on freezing tolerance, via modulation of phytohormone pools. The hormone levels and their metabolism were compared in winter barley under moderate temperature $+/$ - FR, during cold stress after FR pre-hardening, and upon direct application of combined FR and cold treatment. This study is part of a broader project on the evaluation of FR functions in cold hardening. A part of this project, focused on membrane lipids, was published recently [68].

\section{Materials and Methods}

\subsection{Plant Materials and Growth Conditions}

Winter barley with good resistance to cold temperature, Hordeum vulgare spp. vulgare var. Nure, was used in this study. After three days of germination, seedlings were planted in wooden boxes $(30 \mathrm{~cm} \times 25 \mathrm{~cm} \times 10 \mathrm{~cm}$ ) filled with soil. The boxes were placed into a PGV-36 growth chamber (Conviron PGV36; Controlled Environments Ltd.; Winnipeg, MB, Canada) equipped with a modular LED light ceiling. Plants were grown at constant $15{ }^{\circ} \mathrm{C}$, with 12 -h photoperiods for fourteen days. The light source was white light (W) provided by a continuous wide-spectrum LED (Philips Lumileds, LXZ25790-y) at $250 \mu \mathrm{mol} \mathrm{m}{ }^{-2} \cdot \mathrm{s}^{-1}$ intensity.

\subsection{Light and Temperature Conditions during Experimental Treatments}

The 18-d plants were separated into two areas. In one area white light at $250 \mu \mathrm{mol} \mathrm{m}{ }^{-2} \cdot \mathrm{s}^{-1}$ intensity was supplied, and the plants in this zone served as control, whereas in the other zone white light was supplemented by FR illumination, with a narrow $750 \mathrm{~nm}$ LED (Edison Edixeon, 2ER101FX00000001), so that the R/FR ratio was modified to 0.5 (Supplementary Figure S1, [68]). The control zones did not contain any FR illumination. The whole experiment consisted of three different variants.

The treatment variants (see Figure 1):

1. The 18-day-old plants were exposed to FR at moderate temperature $15^{\circ} \mathrm{C}$ for 10 days (FR-M). During FR exposition, the plants reached the four-leaf stage [69].

2. The 28-day-old (FR pre-hardened) plants from variant (1) were exposed to $5{ }^{\circ} \mathrm{C}$ for another 7 days (at high FR) [FR-M/FR-C(28)]. At the end of the stress treatment the plants were 34 days old.

3. The 18-day-old plants were exposed directly to a combination of cold $5{ }^{\circ} \mathrm{C}$ and high FR for 7 days [FR-C(18)].

Samples were collected during the first and the last days of each treatment during a roughly 2-h period between 6 to 8 a.m. (ZT6 to ZT8) daytime. Cold treatment was applied by gradually decreasing the temperature from $15{ }^{\circ} \mathrm{C}$ to $5{ }^{\circ} \mathrm{C}$ during the night, before the additional FR light was switched on in the morning.

\subsection{Measurements of Electrolyte Leakage Levels in Leaf Samples}

Freezing tests were performed according to [70]. The leaf samples were taken on the last day of each of the experimental variants. Two-mm-long leaf segments were sampled from each treatment. In the FR-M and FR-M/FR-C(28) treatments, twelve, and in FR-C(18) treatment, eight segments, were placed in 14-mL Falcon tubes (Thermo Fisher Scientific Inc., Wilmington, MA, USA). Leaf segments from four different plants were combined. Afterwards they were placed into a GP200-R4 liquid freezing system (Grant Instruments, Shepreth, England) in five biological repetitions per treatment and freezing point. To simulate cold acclimation (as under field conditions), the samples were kept at $-2{ }^{\circ} \mathrm{C}$ for $18 \mathrm{~h}$. Subsequently, the samples from FR-M and $\mathrm{W}$ control were frozen at $-5,-7$, and $-9{ }^{\circ} \mathrm{C}$, whereas the samples from FR-M/FR-C(28) and FR-C(18) (and the corresponding 
$\mathrm{W}$ controls) were frozen at $-8,-10$, and $-12{ }^{\circ} \mathrm{C}$ for one hour. For the determination of electrolyte leakage, $8 \mathrm{~mL} \mathrm{MQ}$ water was added to each tube. The samples were shaken gently for two hours before the measurements. Electrolyte leakage was determined by conductometer (Mikro KKT, Budapest, Hungary). For the data analysis, Multi-Sample Conductometer version 1.0 (Intron Software, Biological Research Centre, Szeged, Hungary (Copyright@ L. Menczel, 2002)) was used.

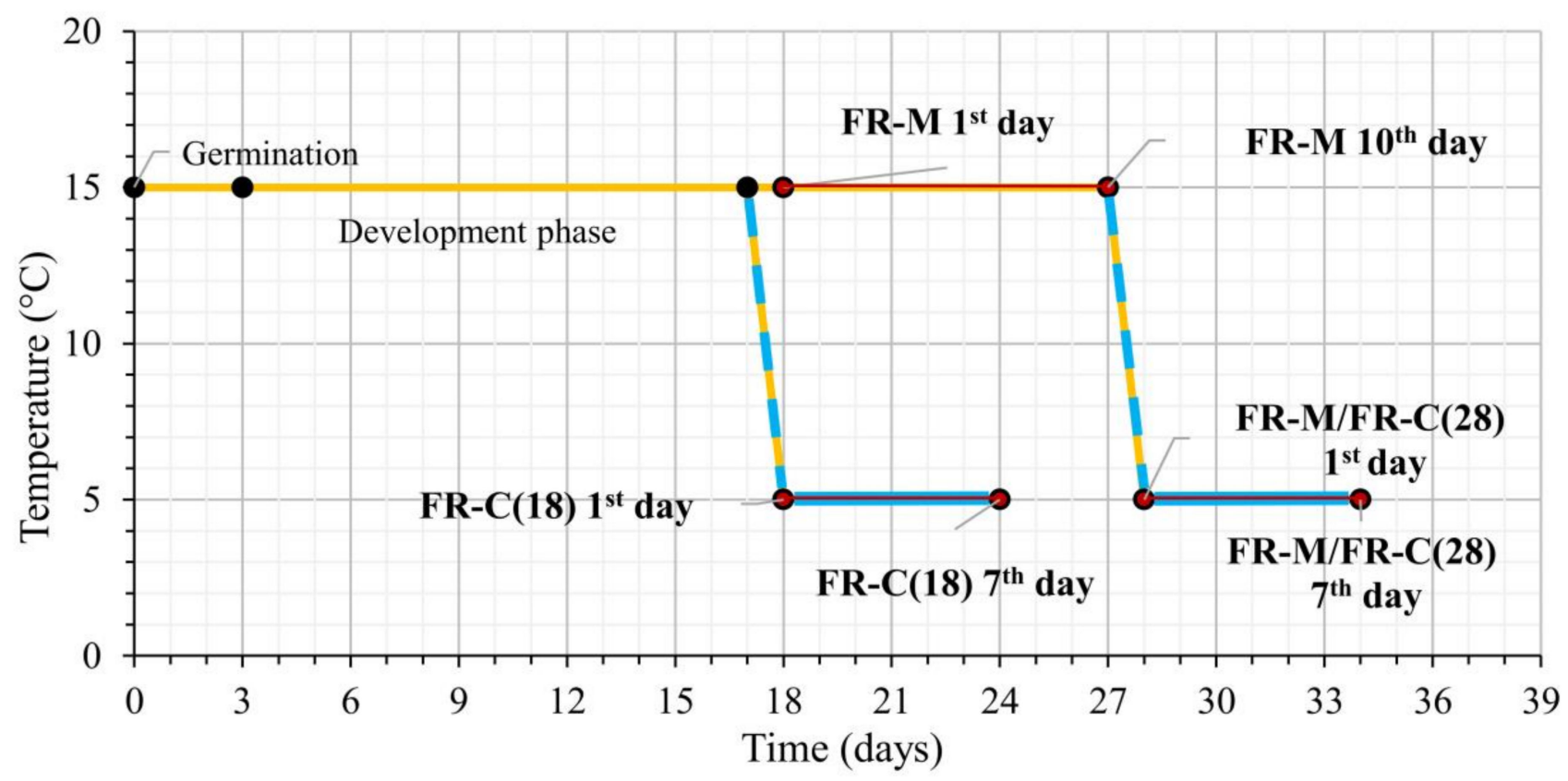

Figure 1. The experimental set-up describing the light and temperature treatments. Treatment 1 (FR-M): The plantlets were exposed to high far-red (FR) at the age of 18 days under constant $15^{\circ} \mathrm{C}$ for 10 days. Treatment 2 (FR-M/FR-C(28)): The plantlets were subjected to high FR for 10 days at $15^{\circ} \mathrm{C}$, then the temperature was dropped to $5{ }^{\circ} \mathrm{C}$ for another seven days (at high FR). Treatment 3 (FR-C(18)): The plantlets were 18 days old when the temperature was dropped to $5^{\circ} \mathrm{C}$ for seven days (at high FR). The red lines represent the FR treatments, while the blue lines indicate the low temperature $5{ }^{\circ} \mathrm{C}$.

\subsection{Hormone Analysis}

Leaf samples were purified and analyzed according to [71] and [72]. Samples were homogenized with a ball mill (MM301, Retsch) and extracted in cold $\left(-20^{\circ} \mathrm{C}\right)$ methanol/water/ formic acid $(15 / 4 / 1 \mathrm{v} / \mathrm{v} / \mathrm{v})$. The following labelled internal standards (10 pmol/sample) were added: ${ }^{13} \mathrm{C}_{6}$-IAA, ${ }^{2} \mathrm{H}_{2}$-OxIAA (Cambridge Isotope Laboratories); ${ }^{2} \mathrm{H}_{4}$-SA (SigmaAldrich, St. Louis, MI, USA, ); ${ }^{2} \mathrm{H}_{3}$-PA (phaseic acid), ${ }^{2} \mathrm{H}_{3}$-DPA (dihydrophaseic acid), ${ }^{2} \mathrm{H}_{4}-7 \mathrm{OH}-\mathrm{ABA},{ }^{2} \mathrm{H}_{5}$-ABA-GE (ABA-glucosyl ester) (NRC-PBI), ${ }^{2} \mathrm{H}_{6}-\mathrm{ABA},{ }^{2} \mathrm{H}_{5}-\mathrm{JA},{ }^{2} \mathrm{H}_{5}-$ transZ, ${ }^{2} \mathrm{H}_{5}$-transZR, ${ }^{2} \mathrm{H}_{5}$-transZ7G, ${ }^{2} \mathrm{H}_{5}$-transZ9G, ${ }^{2} \mathrm{H}_{5}$-transZOG, ${ }^{2} \mathrm{H}_{5}$-transZROG, ${ }^{2} \mathrm{H}_{5}$ transZRMP, ${ }^{2} \mathrm{H}_{3}$-DHZ, ${ }^{2} \mathrm{H}_{3}$-DHZR, ${ }^{2} \mathrm{H}_{3}$-DZRMP, ${ }^{2} \mathrm{H}_{7}-\mathrm{DZOG},{ }^{2} \mathrm{H}_{3}$-DHZ9G, ${ }^{2} \mathrm{H}_{7}-\mathrm{DZOG}$, ${ }^{2} \mathrm{H}_{6}$-iP, ${ }^{2} \mathrm{H}_{6}$-iPR, ${ }^{2} \mathrm{H}_{6}$-iP7G, ${ }^{2} \mathrm{H}_{6}$-iP9G, ${ }^{2} \mathrm{H}_{6}$-iPRMP (Olchemim). Extracts were purified using a mixed mode reverse phase-cation exchange SPE column (Oasis-MCX, Waters). Two hormone fractions were sequentially eluted: (1) fraction $\mathrm{A}$, eluted with methanol containing ABA, IAA, SA, and JA, and (2) fraction B, eluted with $0.35 \mathrm{M} \mathrm{NH}_{4} \mathrm{OH}$ in $60 \%$ methanol containing CKs. Hormone metabolites were analyzed using HPLC (Ultimate 3000, Dionex) coupled to a hybrid triple quadrupole/linear ion trap mass spectrometer (3200 Q TRAP, Applied Biosystems). Quantification of hormones was done using the isotope dilution method with multilevel calibration curves ( $2>0.99)$. Data processing was carried out with Analyst 1.5 software (Applied Biosystems). Data are presented as means \pm standard error. Three biological replicates were analyzed. 


\subsection{Gene Expression ( $q P C R$ )}

In every experimental variant, $50 \mathrm{mg}(\mathrm{FW})$ leaf samples were collected on the first and the last day of the treatments. Total RNA was isolated with Direct-zolTM RNA MiniPrepkit (Zymo Research Corp., Irvine, CA, USA) and its quantity was determined by NanoDrop 2000 spectrophotometer (Thermo Fisher Scientific Inc., Wilmington, MA, USA). According to the manufacturer's protocol, cDNA libraries were prepared with the Moloney Murine Leukemia Virus (M-MLV) Reverse Transcriptase and oligo (dT) 18 primer (Promega Corporation, Madison, WI, USA). For the analysis of the gene expression levels CFX96 TouchTM real-time PCR Detection System (Bio-Rad Hungary Ltd., Budapest, Hungary) and KAPA SYBR ${ }^{\circledR}$ FAST, Master Mix $(2 \times)$, Universal qPCR Kit (Kapa Biosystems, Inc., Wilmington, MA, USA) were used. With respect to the qPCR primers, some were our own design and some were as previously published (Supplementary Table S1; [10]). Cyclophilin was used as reference gene and relative expression levels were calculated by the $\Delta \Delta \mathrm{Ct}$ method [73].

\subsection{Statistical Analysis}

For the statistical evaluation of the data, SPSS 16.0 was used. The homogeneity of the variances was checked by Levene's test, and normality was tested by Kolmogorov-Smirnov probe. To explore differences between treatments, a one-way ANOVA test was performed. Then, in justified cases additional Dunnett T3 or Tukey's-b post hoc tests were applied. Student's $t$ test was used to evaluate the results of the freezing test.

\section{Results}

\subsection{The Effects of FR-Supplemented Light on Freezing Tolerance}

The effect of FR on freezing tolerance was evaluated in barley leaves. The comparison of supplementary FR treatment at $15{ }^{\circ} \mathrm{C}$ and at $5{ }^{\circ} \mathrm{C}$, both after FR pre-treatment (at $15^{\circ} \mathrm{C}$ ) and simultaneously with the temperature drop, revealed significant differences among the experimental variants. The electrolyte leakage measurements showed a positive effect of FR supplementation (Figure 2). The results shown in Figure 2A,B were already mentioned in our study of the effect of FR and cold on lipid composition [68]. Here we analysed three treatments (Figure 2C). In the first treatment at $15^{\circ} \mathrm{C}(\mathrm{FR}-\mathrm{M})$, the FR effect reached statistical significance only at a freezing temperature of $-7^{\circ} \mathrm{C}$. The most remarkable freezing tolerance improvement between the $\mathrm{W}$ control and the FR-treated samples was observed at prolonged FR exposure FR-M/FR-C(28) (i.e., FR pre-hardening + low temperature treatment at high FR presence), both at $-10{ }^{\circ} \mathrm{C}$ as well as at $-12{ }^{\circ} \mathrm{C}$. In the case of the combination of cold and light treatment (FR-C(18) and the corresponding $\mathrm{W}$ control), significant change occurred at a freezing temperature of $-12{ }^{\circ} \mathrm{C}$. Membrane damage was lower after plant acclimation to low temperature $\left(5^{\circ} \mathrm{C}\right)$ than in plants grown at $15^{\circ} \mathrm{C}$ (Figure 2A) independently from light quality (Figure 2B,C). In the case of the younger seedlings (18 days old at the beginning of the treatment) further improvement was observed both in the control W samples and in the FR supplementation, which further enhanced freezing tolerance (Figure 2C). The results indicate that the FR enrichment positively influences the plant's freezing tolerance at low temperature. It may be concluded that freezing tolerance is affected by low temperature, FR enrichment in the case of $\mathrm{W}$, as well as plant developmental stage. 


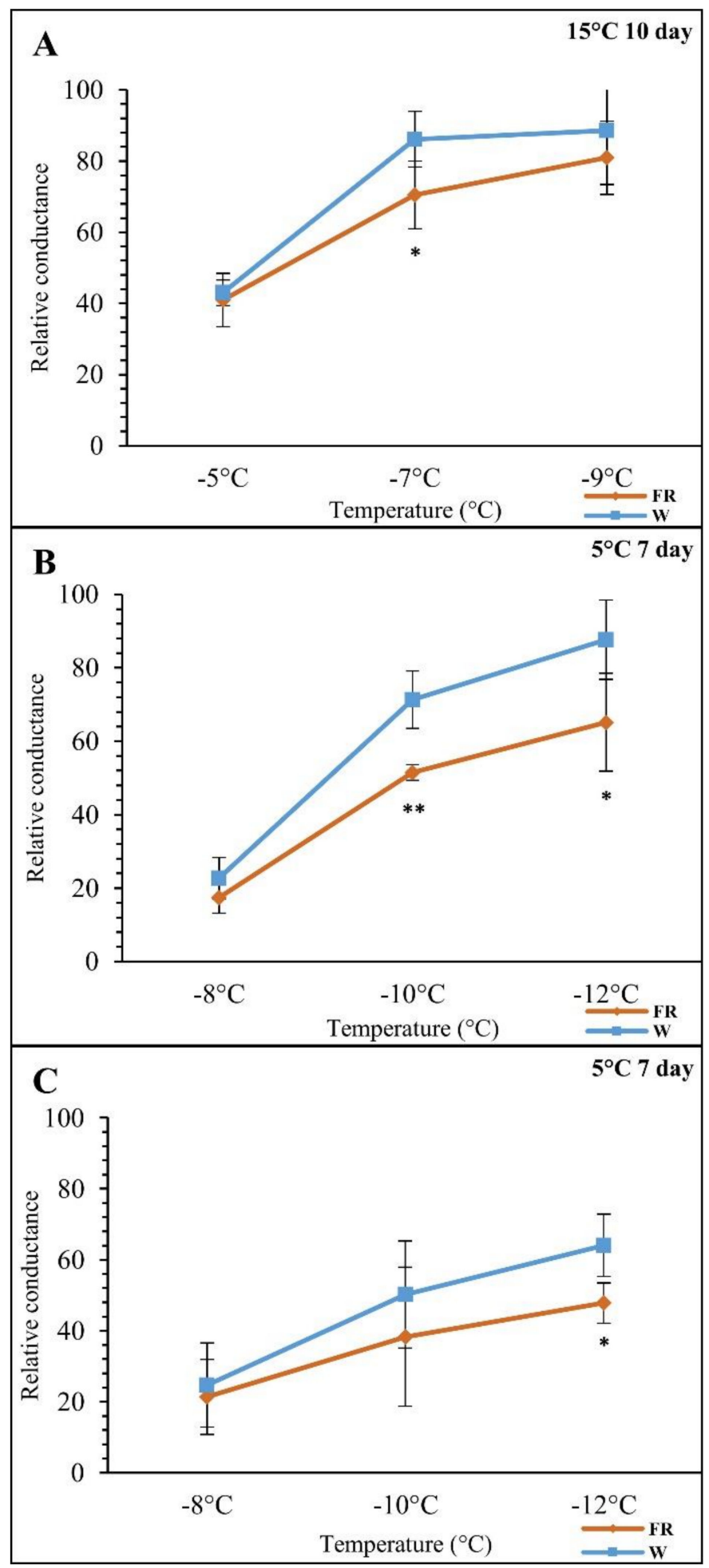

Figure 2. The effects of the supplementary far-red light treatments (FR) on plants' freezing tolerance determined on the basis of electrolyte leakage. The relative conductance values correspond to percentage of lethality. (A) (FR-M): FR treatment at $15^{\circ} \mathrm{C}$ for 10 days (treatment began on day 18). (B) (FR-M/FR-C(28)): FR pre-treatment at $15^{\circ} \mathrm{C}$ for 10 days followed by cold stress at $5{ }^{\circ} \mathrm{C}$ for 7 days (cold treatment began on day 28). (C) (FR-C(18)): Combined cold $\left(5^{\circ} \mathrm{C}\right)$ and FR treatment for 7 days (treatment began on day 18). W: white light; FR: far-red-enriched light. The data are mean values from five biological replicates. Significance of difference between the control $\mathrm{W}$, and the FR treated samples is designated as ${ }^{*} p<0.05$ and ${ }^{* *} p<0.01$ with Student's $t$ test. 


\subsection{Alterations in Plant Hormone Levels during Treatments}

As phytohormones regulate cold acclimation in an intensive cross-talk, five hormones were followed in the experiments. The impact of FR was compared at different temperatures, treatment lengths, as well as plant ages. Significant differences were detected in the hormone levels and their metabolism (Figures 3 and 4, Supplementary Table S2), namely in case of ABA, JA, SA, IAA, and CKs, and especially of cis-zeatin-type.

A

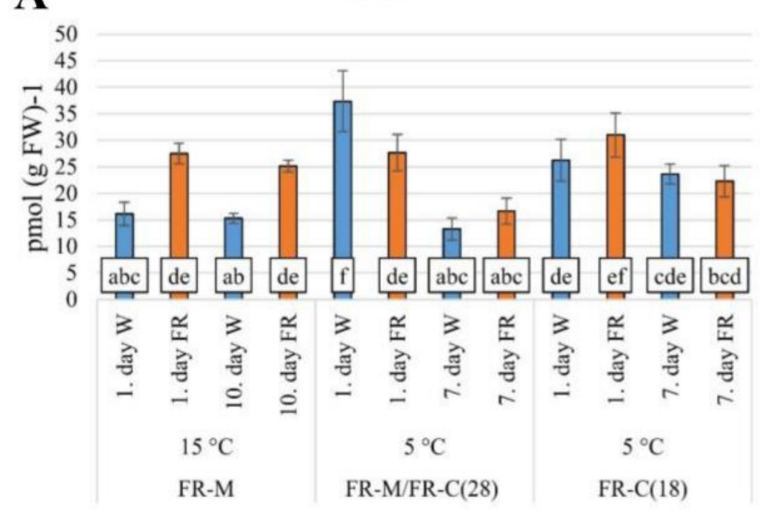

C

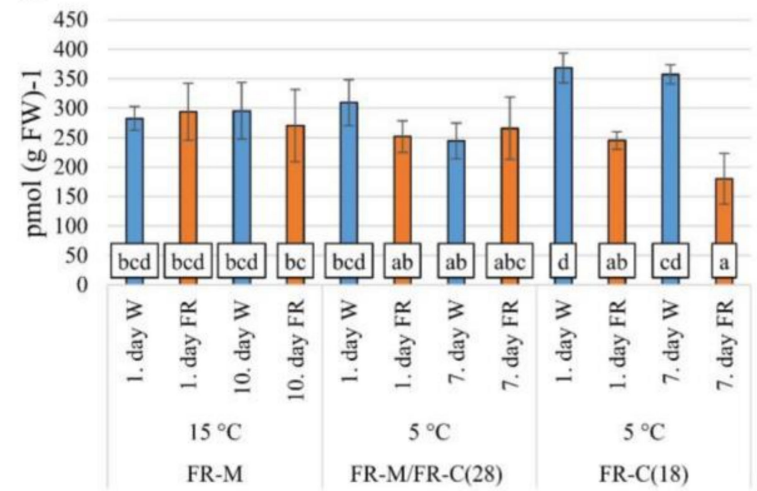

B

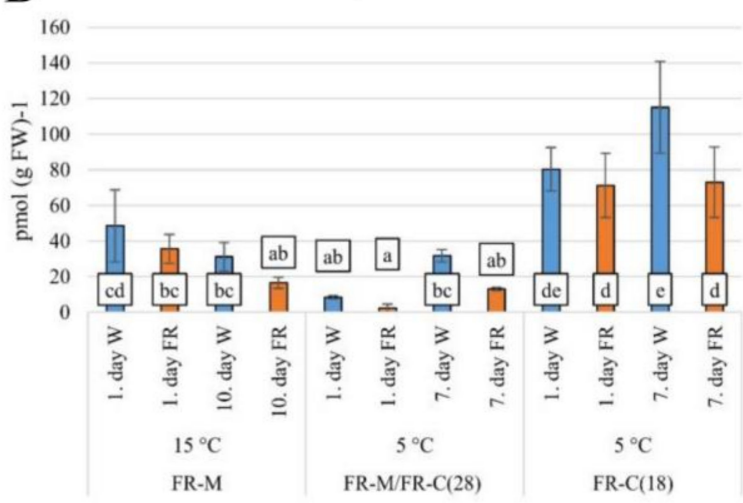

D

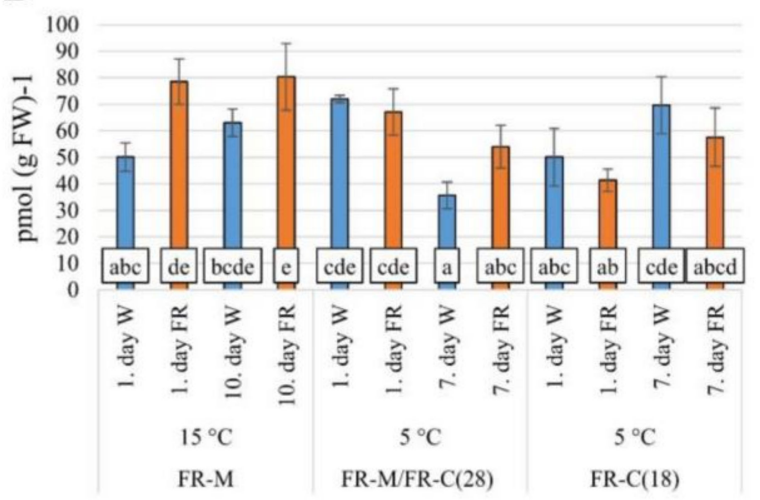

Figure 3. The impact of FR enrichment and moderate or low temperature on hormone concentrations. (A): ABA, abscisic acid; (B): JA, jasmonic acid; (C): SA, salicylic acid; (D): IAA, indole-3-acetic acid. Leaf samples were collected six to eight hours after the start of illumination. Plantlets were grown under $12 \mathrm{~h}$ photoperiod. FR-M: FR treatment at $15^{\circ} \mathrm{C}$ for 10 days. FR-M/FR-C(28): FR treatment at $15{ }^{\circ} \mathrm{C}$ for 10 days + FR treatment at $5{ }^{\circ} \mathrm{C}$ for 7 days. FR-C(18): FR treatment at $5{ }^{\circ} \mathrm{C}$ for 7 days. Plant age at the start of the cold treatment was 28 days in the case of FR-M/FR-C(28) and 18 days in FR-C(18) variant. W: white light, FR: far-red-enriched white light. Mean and standard deviation values were calculated from three biological replicates. Significant differences between the columns were determined by Tukey's-b test $(p<0.05)$.

FR treatment at $15^{\circ} \mathrm{C}$ (FR-M) almost doubled the ABA content after $7 \mathrm{~h}$ (Figure 3A), and that difference remained steady during the following 10 days. As expected, the cold treatment $\left(5^{\circ} \mathrm{C}\right)$ increased significantly $(p<0.05)$ the ABA content in the control W illuminated samples after $7 \mathrm{~h}$, surpassing the level of the FR-treated samples. The temperature drop had only a moderate effect on the ABA concentration in the FR-acclimated samples after $7 \mathrm{~h}$ of cold. After 7 days of cold treatment, ABA content decreased both in the control $\mathrm{W}$ - and in the FR-treated samples (Figure 3A, FR-M/FR-C(28)). At the beginning of the FR-C(18) treatment the plantlets were younger (18 days old) than at the FR-M/FR-C(28) (28 days, Figure 1 ) when the temperature dropped to $5{ }^{\circ} \mathrm{C}$. Another difference was that in the case of FR-C(18) the experimental variant FR-treatment started together with the temperature shift. Both the $\mathrm{W}$ control and the FR-treated plants responded similarly to low temperature, although the ABA content in the FR-treated samples surpassed that of 
the $\mathrm{W}$ control samples after $7 \mathrm{~h}$. Most likely the combination of the two external abiotic factors affected ABA metabolism synergistically. Interestingly, the elevated ABA content was partially preserved after a seven-day cold treatment both in the $\mathrm{W}$ - and FR-treated samples, a phenomenon that can be explained by the maintenance of an activated defense level in younger plants.

A

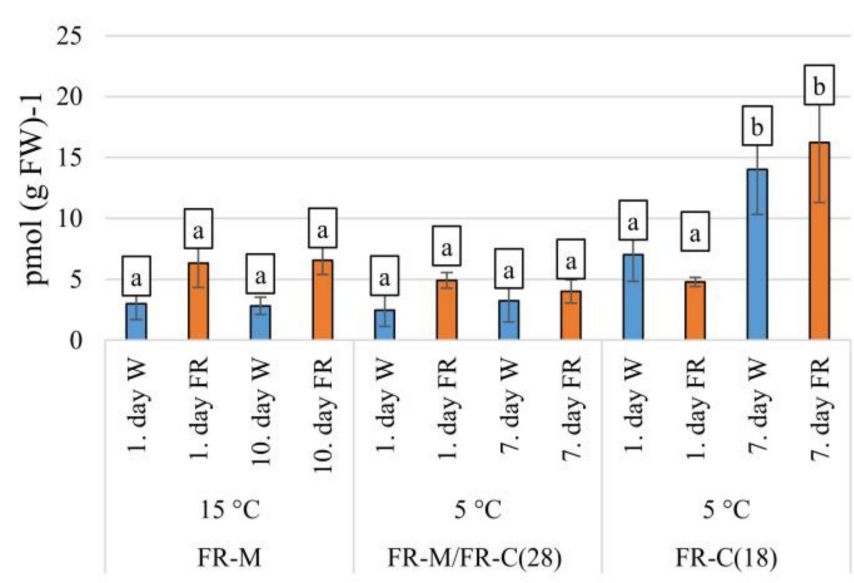

B

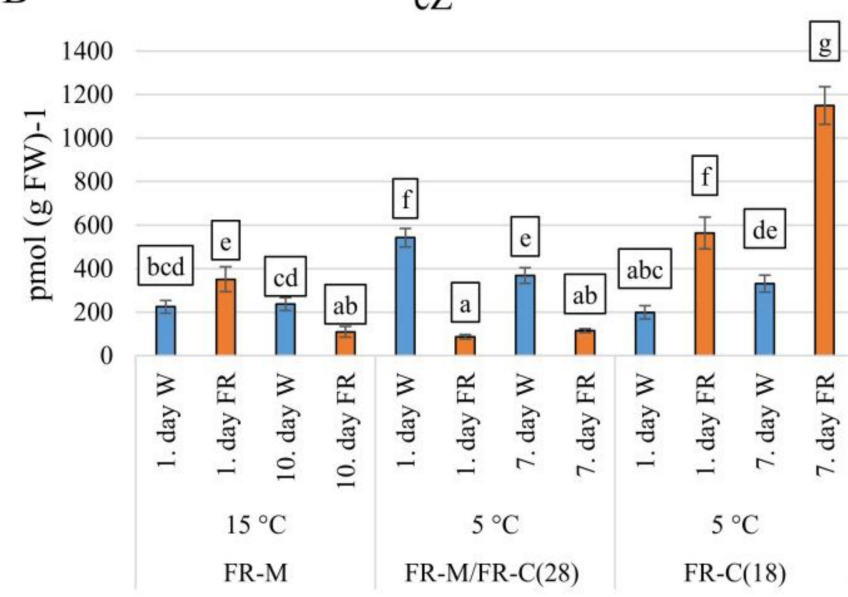

Figure 4. The impact of FR enrichment and moderate or low temperature on active cytokinin concentrations. (A): $t Z$, trans-zeatin; (B): cZ, cis-zeatin. Conditions are the same as in Figure 3.

FR supplementation had a moderate negative effect on JA levels at $15{ }^{\circ} \mathrm{C}$ (2-fold decrease after 10 days, Figure 3B). The low temperature caused a transient down-regulation of JA content in all the samples. FR pre-treatment strengthened the cold effect in the FR-treated plants (4-fold decrease), especially at the early phase of the response. In the case of cold treatment of young plants (18-d old), JA content was doubled within the first day of the cold stress, irrespective of light treatment, and increased still further after 7 days at $5{ }^{\circ} \mathrm{C}$ in W. The FR-treated plants maintained the level reached after 7-h of cold.

Neither FR nor cold treatments affected SA content significantly during the first two treatments (FR-M, FR-M/FR-C(28) and the corresponding W controls, Figure 3C). During cold treatment of young plants (18-d old), SA content changed similarly to JA. Upon cold exposure, SA content moderately increased in $\mathrm{W}$, whereas this elevation was inhibited significantly $(p<0.05)$ by FR-supplementation.

IAA content (Figure 3D) was up-regulated almost two-fold during the first day of FR treatment at $15^{\circ} \mathrm{C}$, and that increase remained steady during the next 10 days (FR-M). This phenomenon is most likely related to the shade avoidance syndrome caused by FR-enriched incident white light. The early response to cold was associated with IAA up-regulation in both the W- and FR-treated plants (FR-M/FR-C(28)). Nevertheless, in the last day of stress a moderate down-regulation was observed in the $\mathrm{W}$ illuminated samples. The FR treatment caused partial maintenance of IAA elevation. In the FR-C(18) experimental variant, combined stress caused a transient IAA down-regulation in FR-treated plants. After 7 days, the moderate IAA elevation may have indicated acclimation in the younger plants, irrespective of light treatment.

The levels of active CKs, trans-zeatin (tZ), dihydrozeatin (DHZ), and isopentenyladenine (iP) were low in comparison with cis-zeatin (cZ). The most physiologically active $\mathrm{CK}$, trans-zeatin (tZ) was moderately enhanced by FR at $15^{\circ} \mathrm{C}$ (FR-M). After 10 days, no significant change was detected (Figure $4 \mathrm{~A}$ ). Cold stress resulted in transient $\mathrm{t} Z$ decrease in white light. Plants pre-treated with FR (FR-M/FR-C(28)) were able to maintain higher $\mathrm{t} Z$ levels at low temperature. At the end of the stress treatment, slight $\mathrm{t} Z$ up-regulation was observed in the comparison with $\mathrm{W}$ exposed plants. Combination of FR and cold 
(FR-C(18)) had no significant effect during the first day; however, significant elevation was found after 7 days of cold, irrespective of light treatment.

FR-treatment caused transient up-regulation in cZ content at $15^{\circ} \mathrm{C}(\mathrm{FR}-\mathrm{M})$ followed by its down-regulation (Figure 4B). After the temperature decrease to $5^{\circ} \mathrm{C}(\mathrm{FR}-\mathrm{M} / \mathrm{FR}-\mathrm{C}(28)$ ), $\mathrm{cZ}$ content increased significantly in the $\mathrm{W}$ illuminated samples. After FR pre-treatment, the supplementary FR light repressed this cold-induced elevation. In contrast, simultaneous application of cold and FR (FR-C(18)) enhanced cZ content 3-fold during 1 day compared to the $\mathrm{W}$ illuminated samples. The $\mathrm{cZ}$ level was further enhanced after 7 days.

\subsection{The Expression Patterns of the Key Hormone Metabolism-Related Genes}

The expression of selected hormone metabolism-related genes was determined by qPCR. All the relative expression values were compared to the first day of the first treatment at $15{ }^{\circ} \mathrm{C}$ (FR-M). The results are shown in the heatmap (Figure 5).

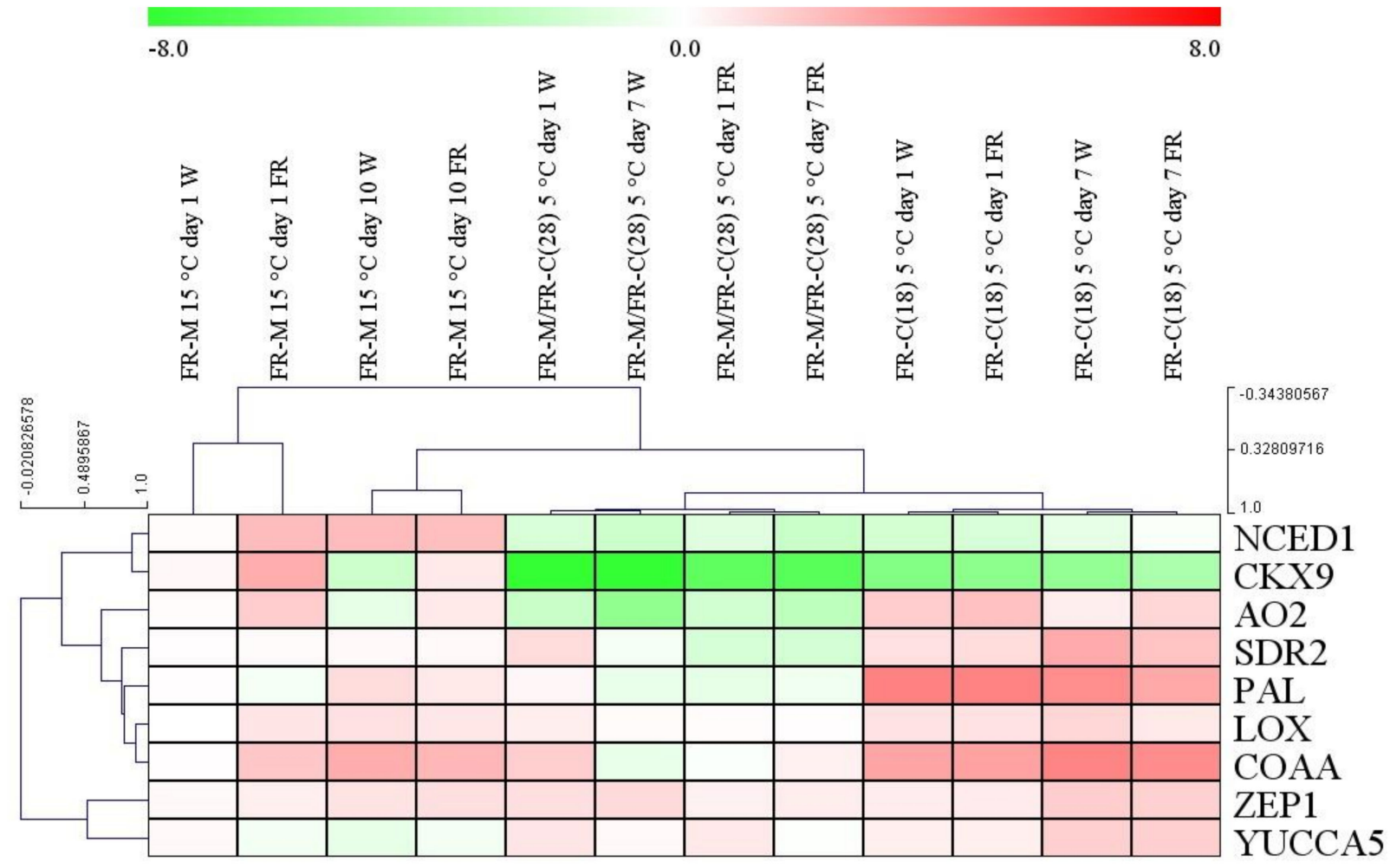

Figure 5. The effect of supplementary FR light and low temperature on the relative expression of the genes related to the hormone metabolism. Leaf samples were collected six to eight hours after the start of illumination. The plantlets were grown under $12 \mathrm{~h}$ photoperiod. Transcript levels were calculated with the $\Delta \Delta \mathrm{Ct}$ method. $\log _{2}$ expression values are shown. W: white light, FR: far-red-enriched white light. The data originated from three biological replicates. The values on the $X$ and $Y$ axis outside of the heatmap refer to the distance or proximity of data after hierarchical clustering.

The treatments clustered separately based on the transcript levels, which clearly showed the importance of the timing of the FR treatments.

Transcription profiles of the ABA biosynthetic genes ZEP1, NCED1, SDR2, and AO2 were determined. The expression of ZEP1 varied only slightly during FR-M and FR-M/FR$C(28)$ treatments. In the FR-C (18) experiment, when the younger plants were cold treated, ZEP1 transcript levels were elevated after 7 days independently from light quality. A large positive effect of FR light on NCED1 expression was detected at $15^{\circ} \mathrm{C}$. At low temperature, NCED1 expression was strongly down-regulated, independently from plant age or light spectra. The other two genes (SDR2 and AO2) behaved similarly, and were clustered very closely together. Their expression was down-regulated, mainly by low temperature, except during the first day of the FR-M experiment, where the expression of $A O 2$ was slightly 
increased. The supplementary FR light, in synergy with the cold, further reduced transcript levels. In the FR-C(18) treatment this phenomenon was quite the opposite: instead of the decreasing pattern, an elevation was observed.

The genes related to JA and SA metabolism ( $L O X$ and $P A L$ ) belong to the same cluster, together with some ABA-related genes. The FR-treatment caused a mild decrease in the expression of these two genes after 10 days at $15^{\circ} \mathrm{C}$. An opposite pattern was observed in the FR-M/FR-C(28) and FR-C(18) experiments, the former one was associated with a mild down-regulation, whereas the latter one with up-regulation (especially of $P A L$ ). The cold treatment of 18-day-old plants induced their expression independently from light quality in the third treatment.

The COAA and YUCCA5 genes were investigated as important genes in auxin biosynthesis. The largest changes were observed in the case of COAA. A 3-fold stimulation of expression was caused by FR supplementation at $15^{\circ} \mathrm{C}$ after $7 \mathrm{~h}(\mathrm{FR}-\mathrm{M})$. Comparison of FR-M/FR-C(28) and the corresponding $\mathrm{W}$ control showed that low temperature eliminated the differences between light treatments. The cold treatment of 18-day-old plants resulted in even larger increases, independently from light quality. The expression pattern of CKX9 was clustered to NCED1. A large, six-fold elevation of CKX9 expression was observed upon FR supplementation to $\mathrm{W}$ at $15{ }^{\circ} \mathrm{C}$ (FR-M). At low temperature, $C K X 9$ expression decreased dramatically (Figure 6-FR-M/FR-C(28) and FR-C(18) treatments).

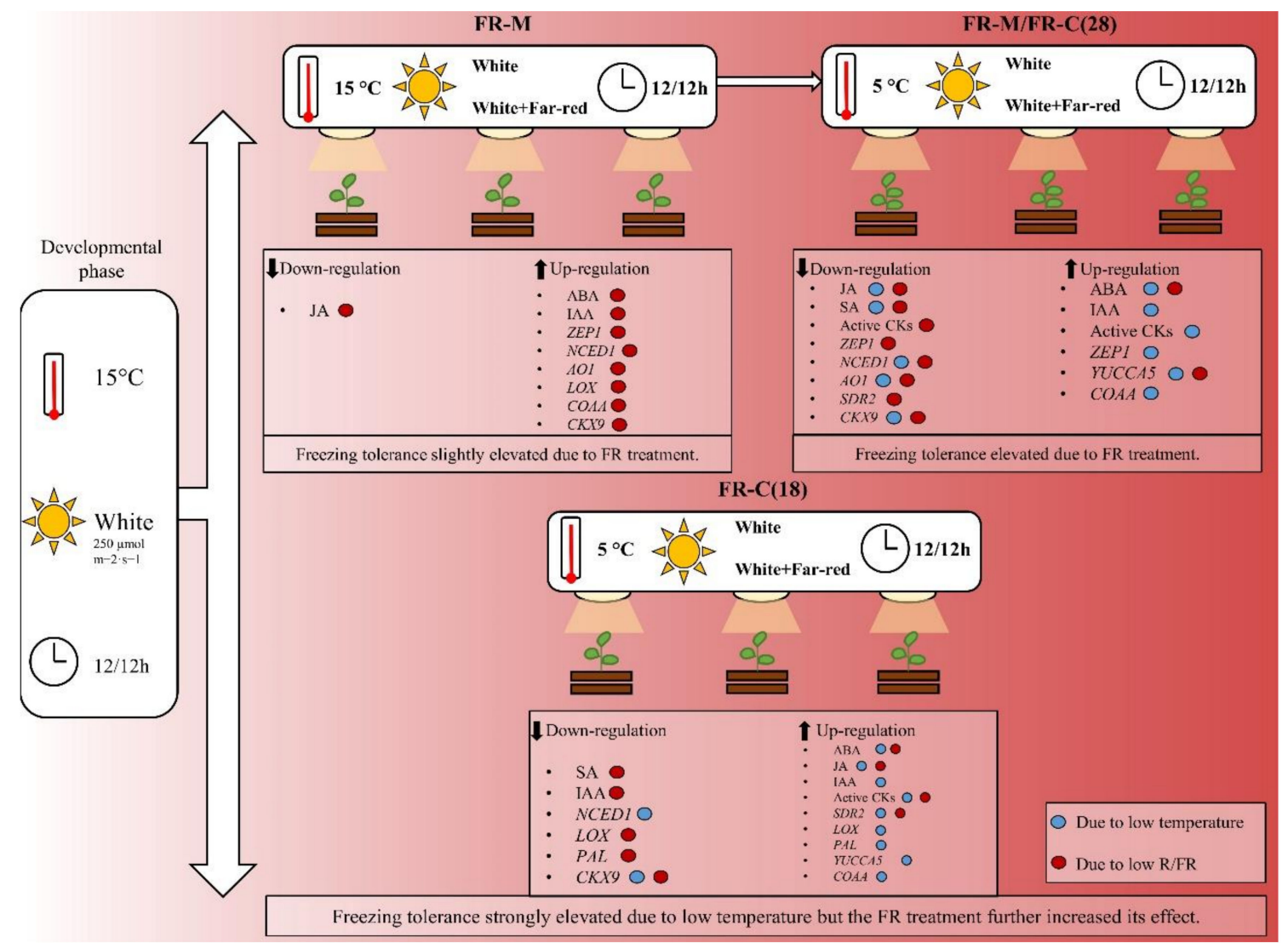

Figure 6. Summary of phytohormone responses and changes in the expression profiles of the key hormone metabolismrelated genes elicited by low temperature treatment and/or FR enrichment. FR-M (Treatment 1): The plantlets were exposed to high FR at the age of $18-28$ days under constant $15^{\circ} \mathrm{C}$. FR-M/FR-C(28) (Treatment 2): The plantlets were subjected to high FR for 10 days at $15^{\circ} \mathrm{C}$, then the temperature was dropped to $5{ }^{\circ} \mathrm{C}$ for seven days (at high FR). FR-C(18) (Treatment 3): The plantlets were 18 days old when the temperature was dropped to $5^{\circ} \mathrm{C}$ for seven days (at high FR). ABA: abscisic acid; IAA: indole-3-acetic acid; JA: jasmonic acid; SA: salicylic acid; cZ: cis-zeatin; active CKs: active cytokinins; CKX9: cytokinin oxidase/dehydrogenase 9; COAA: acetyl-CoA acetyltransferase; YUCCA5: indole-3-pyruvate monooxygenase; ZEP1: zeaxanthin epoxidase; NCED1: 9-cis-epoxycarotenoid dioxygenase1; SDR2: short-chain dehydrogenase; AO2: aldehyde oxidase 2; LOX: lipoxygenase; PAL: phenylalanine ammonia-lyase. 
In general, except for $C K X 9$, the larger changes occurred mostly upon the cold exposure of 18-day-old plants. In this experimental setup the treated plants were not preacclimated to FR enriched light, and were still at the beginning of the three-leaf stage. Similarly to phytohormone content, the most pronounced interaction between FR and cold treatments was displayed here.

\section{Discussion}

\subsection{FR Impact at Moderate Temperature}

Plants perceive light by different photoreceptors. The only photoreceptor activated by FR is phytochrome A (PhyA). This photoreceptor was reported to enhance plant freezing tolerance $[67,74,75]$. The positive effect of the enhanced FR/R ratio associated with PhyA activation is in accordance with our data on FR-induced promotion of freezing tolerance in barley at $15^{\circ} \mathrm{C}$ (Figure 2). This finding is in line with our previous study [61], where a positive effect of FR enrichment on the expression of the key cold-inducible transcription factor CBF14 was demonstrated at $15^{\circ} \mathrm{C}$. However, the precise mechanism of the FR effect on cold acclimation has not yet been revealed. In our previous studies we demonstrated in cereals (both in wheat and barley) that an effect of FR can be further increased by higher light intensity $[61,62]$. It should also be mentioned that in spring barley varieties grown at normal growth temperature, FR light is less effective than other modifications like blue light enrichment in the illuminating light [76].

Apart from the effect of FR on freezing tolerance, an adaptation reaction to autumnal changes in the composition of the light spectrum, the enhanced FR/R ratio may also be sensed by plants as a marker of shading, because plants use $\mathrm{R}$ light for photosynthesis and reflect FR. In dense vegetation this provokes the shade avoidance syndrome, which in dicots is associated with promotion of hypocotyl/stem growth and suppression of leaf development [77], and in monocots with stem elongation and subsequent reduced number of spikelets and filled grains [78]. These developmental changes, as well as cold acclimation, are regulated by plant hormones, and thus their change imposed by FR exposure might be related to cold hardening, shade avoidance syndrome, or both.

The most prominent change after FR supplementation at $15^{\circ} \mathrm{C}$ was the up-regulation of ABA content (Figure $3 \mathrm{~A}$ ), together with stimulation of the expression of the gene for its rate-limiting biosynthetic enzyme NCED1, as well as of other ABA biosynthetic genes such as $A O 2$, and, to a lesser extent, ZEP1 and SDR2 (Figure 5). This is in accordance with other studies, which reported that genes related to ABA biosynthesis are strongly up-regulated by FR supplementation $[79,80]$. The low R/FR ratio can up-regulate ABA in A. thaliana in order to inhibit bud outgrowth [81]. The function of ABA in cold hardening seems to be given (at least partially) by stimulation of the expression of protective substances, e.g., LEA proteins [5], or by suppression of growth [82].

Down-regulation of JA during prolonged FR exposure at $15{ }^{\circ} \mathrm{C}$ (Figure 3B) is in accordance with its suppression during shade response, associated with enhanced plant vulnerability to herbivore attack at low $\mathrm{R} / \mathrm{FR}$ ratio [83]. In $A$. thaliana, low $\mathrm{R} / \mathrm{FR}$ ratio repressed the JA-induced defense responses, probably due to the fact that plants need to relocate their energy resources from the stimulation of defense to rapid elongation [84]. FR light also negatively influenced JA biosynthesis in spring barley leaves [76]. Apart from diminished JA content, its signalling pathway was also reported to be suppressed, as FR-induced phytochrome B inactivation leads to stabilization of JA repressors-JAZ proteins (JASMONATE ZIM DOMAIN) [85].

The low $\mathrm{R} / \mathrm{FR}$ ratio adversely affects not only JA-dependent but also SA-dependent defenses in A. thaliana [86]. The shade-avoidance response is prioritised over plant immune responses $[84,86]$. However, only mild SA decrease was detected in barley upon prolonged FR (Figure 3C).

The hormone generally elevated during the shade avoidance response is IAA $[87,88]$. Indeed, significant up-regulation of this auxin was detected during the whole period of FR exposure at $15^{\circ} \mathrm{C}$ (Figure 3D), together with promotion of the expression of COAA 
(Figure 5). It is known that IAA over-producing plants have an up-regulated activity of CKX, the main CK-degrading enzyme $[77,89]$. The increase in IAA coincided with significant up-regulation of CKX9 (Figure 5). This correlates well with the decrease of active CKs after 10 days at high FR (Figure 4), and is in accordance with the fact that shade avoidance is usually associated with a decrease in CKs, related to inhibition of leaf growth (in favour of hypocotyl elongation) [90].

\subsection{The Effect of FR Pre-Treatment on Cold Stress Response}

The results of the electrolyte leakage analysis (Figure 2) showed that pre-treatment with FR had a strong positive effect on freezing tolerance after subsequent cold treatment at $5{ }^{\circ} \mathrm{C}$ (FR-M/FR-C-(28)). Decrease of the temperature to $5{ }^{\circ} \mathrm{C}$ resulted, in $\mathrm{W}$ grown plants, in a strong, transient up-regulation of ABA (Figure 3A). This rise of ABA is in accordance with previous reports $[5,91]$. Thus, low temperature exhibited a similar effect on ABA metabolism as FR treatment at $15{ }^{\circ} \mathrm{C}$. Cold, among other stress cues (salinity, dehydration, heat), strongly influences $\mathrm{ABA}$ levels by activating many genes involved in the biosynthetic pathway [92]. Plant priming with FR diminished the subsequent coldinduced ABA elevation during one day of cold stress. The reason for this may be an enhanced cold tolerance caused by FR pre-treatment, which diminished the stress strength, and was thus associated with lower stress response. Later on, the level of ABA decreased in both light regimes. The ABA decrease during prolonged cold treatment is in accordance with previous reports, e.g., [5]. The ABA profile coincided with the expression of SDR2 and AO2. Low NCED1 transcript level may indicate that ABA elevation in leaves was promoted by its transport from the roots.

JA levels were rather low at the early cold stress response (Figure 3B) and moderately elevated later on. This is in accordance with the report by [93]. The negative effect of FR, observed already at $15{ }^{\circ} \mathrm{C}$, was maintained during the whole cold period (Figure 3B). Only minor changes were observed in the case of SA (Figure $3 \mathrm{C}$ ). Moderate down-regulation of the expression of $P A L$ agrees with a mild decrease in SA under FR at the beginning of the cold period.

The effect of FR on IAA was abolished during one day at $5{ }^{\circ} \mathrm{C}$ (Figure 3D), which indicates that temperature has a stronger impact than light composition. Later on, the positive effect of FR was clearly visible. Cold stress had a moderate negative effect on $\mathrm{tZ}$, the most active $\mathrm{CK}$ in stimulation of cell division. In contrast, content of $\mathrm{cZ}$, the low active $\mathrm{CK}$ often related to stress responses, increased. Later on, $\mathrm{tZ}$ slightly increased, whereas cZ moderately decreased, which may indicate plant acclimation to low temperature. In accordance with the treatment at $15^{\circ} \mathrm{C}, \mathrm{FR}$ also exhibited a negative effect on $\mathrm{CZ}$ at $5{ }^{\circ} \mathrm{C}$. The slightly higher $\mathrm{t} Z$ content in FR-treated plants during 1 day may reflect higher stress tolerance given by FR pre-treatment and thus a diminished stress effect.

\subsection{Combined FR and Cold Stress}

In the FR-C(18) treatment, cold stress was applied simultaneously with FR supplementation to young 18-day-old plants. In comparison with the FR-M/FR-C(28) experiment, younger plants already exhibited significantly higher stress tolerance in white light (Figure 2). It seems that plants are more sensitive to low temperature during the three leaf developmental stage compared to later stages of their development. The early elevation of ABA was slightly lower in comparison with 28-day-old plants. The most plausible explanation for this phenomenon is the following: In the temperate region of the northern hemisphere the sowing period of winter cereals begins in the first-second week of October and continues until November. Consequently, when the first frosty spells affect the developing plants (night frost generally appears at the beginning of November) they are still in the very young phase of their development (2-3 leaf stage). So, for several hundred years the farmers/breeders selected unintentionally for variants which were able to adapt to this harsh climate. Indeed, it was published recently that light quality and quantity affected wheat and barley growth and development and even the output of 
circadian clock $[65,94-96]$. Simultaneously, up-regulation of JA and SA was much more profound than in the FR-M or FR-M/FR-C(28) experiments. The hormone profiles are in accordance with the expression patterns of their biosynthetic genes; strong stimulation was detected in the case of SA-related gene PAL and, to lesser extent, of JA-related gene $L O X$. This is in accordance with previous reports, which showed that low temperature or cold acclimation usually results in elevated PAL activity, e.g., in festulolium or rape plants $[97,98]$. Most likely, the plantlets prioritize keeping their defense mechanisms alert against extreme environmental conditions in this developmental stage. At the end of the 7-day cold period, all stress hormones, especially JA, were elevated. Stimulation of LOX was in contrast to the results of Liu et al. [99], who reported cold-induced suppression of several LOX genes in oriental melon. However, the response may be species specific and, moreover, various LOX genes may be subject to different modes of regulation.

The combination of cold and FR was found to induce an enhanced cold acclimation, compared to cold alone, since the level of ABA was increased, while IAA was decreased. The difference in ABA accumulation between FR-M/FR-C(28) and FR-C(18) may have been due to FR pre-treatment in the former case, which is in accordance with the difference between non-acclimated and cold-acclimated barley [100]. FR caused a substantial increase of the stress-related CKs (cZ). FR imposed a significant negative effect on JA after 7 days (as during shade response), strongly suppressing SA levels. Both hormone levels and the expression profiles of hormone metabolism-related genes indicated that an activated defense was maintained during the whole cold treatment. The increase in IAA (together with high CK content), which is in accordance with up-regulation of YUCCA5 and COAA expression, seems to indicate that young plants were able to acclimate better to stress conditions.

\subsection{Summary}

FR-supplemented white light acts as a coordinator in the pre-hardening process, aside from its regulation of many plant developmental and physiological processes. Supplementary FR light had a positive impact on the plants' cold tolerance, even at moderate temperature. This effect was strengthened by cold treatment at $5{ }^{\circ} \mathrm{C}$, in comparison with a non-cold hardening temperature. The results of the hormone and the qPCR analyses indicate that the combination of these two environmental factors enhanced some impacts, as well as suppressing the other imposed by FR or cold separately. A summary of the data is shown in Figure 6. The synergistic effects of these two environmental cues on freezing tolerance indicate that their combination represents a unique environmental signal, which is a part of plant adaptation to seasonal variations in temperate zones. Even if the effect of low temperature had a greater impact on plant behaviour than modification of light spectrum, the timing and duration of the FR treatment seem to be crucial factors in cold acclimation processes, as far as plant acclimation is concerned. Another important factor is plant age. Cold hardening was more efficient in the early developmental stages of barley plants, which was associated with higher stimulation of plant defenses, as indicated by the comparable elevation of ABA and higher increase of JA and SA.

\section{Conclusions}

Characterization of the FR effects on dependence on temperature showed a close relationship between plant hormones, light quality, and low temperature during the cold acclimation process. The significant modulation of phytohormone pools and the related transcriptome by the FR enrichment at moderate or low temperature was in all cases associated with elevated frost tolerance. Comparing the response of plants at the three-leaf stage and at later developmental stage revealed that the concentrations of SA, JA, and the active CKs exhibited significant promotion in the younger plants. As the experimental system presented here mimicked well the late autumn situation in the temperate and boreal climates of the northern hemisphere, it seems that elevated protection against low temperature can occur in plants as an adaptation to autumn-related environmental changes, distinct from the shade avoidance syndrome. 
Supplementary Materials: The following are available online at https:/ / www.mdpi.com/2218-273 X/11/3/450/s1.

Author Contributions: G.G. supervised and managed this study. K.G. isolated the total RNA samples and prepared the cDNA libraries for qPCR. T.P. performed the qPCR measurements with M.A. P.D. made the MS analysis. R.V. supervised the hormone analysis and corrected parts of the manuscript. M.A. raised the plants, collected the leaf samples, performed the qPCR, measured the electrolyte leakage levels, evaluated the data, made the statistical analysis and wrote the manuscript. All authors have read and agreed to the published version of the manuscript.

Funding: This work was supported by the National Research, Development and Innovation Office 'OTKA' K 128575 and by the EFOP-3.6.3-VEKOP-16-2017-00008 projects and by Ministry of Education, Youth and Sports of CR No. CZ.02.1.01/0.0/0.0/16_019/0000738. The project was co-financed by the European Union and the European Social Fund.

Institutional Review Board Statement: Not applicable.

Informed Consent Statement: Not applicable.

Acknowledgments: The authors wish to thank to Mónika E. Fehér from Department of Plant Molecular Biology, Agricultural Institute, Centre for Agricultural Research, Martonvásár, Hungary for her technical assistance and to Alena Gaudinová from Institute of Experimental Botany of the Czech Academy of Sciences, Prague, Czech Republic who prepared the samples for MS analysis.

Conflicts of Interest: The authors declare no conflict of interest.

\section{References}

1. Foyer, C.H.; Noctor, G. Redox homeostasis and antioxidant signaling: A metabolic interface between stress perception and physiological responses. Plant Cell 2005, 17, 1866-1875. [CrossRef] [PubMed]

2. Fujita, M.; Fujita, Y.; Noutoshi, Y.; Takahashi, F.; Narusaka, Y.; Yamaguchi-Shinozaki, K.; Shinozaki, K. Crosstalk between abiotic and biotic stress responses: A current view from the points of convergence in the stress signaling networks. Curr. Opin. Plant Biol. 2006, 9, 436-442. [CrossRef] [PubMed]

3. Kurepin, L.V.; Dahal, K.P.; Savitch, L.V.; Singh, J.; Bode, R.; Ivanov, A.G.; Hurry, V.; Hüner, N.P.A. Role of CBFs as integrators of chloroplast redox, phytochrome and plant hormone signaling during cold acclimation. Int. J. Mol. Sci. 2013, 14, 12729-12763. [CrossRef]

4. Galiba, G.; Vanková, R.; Tari, I.; Bánfalvi, Z.; Poór, P. Plant and Microbe Adaptations to Cold in a Changing World; Imai, R., Yoshida, M., Matsumoto, N., Eds.; Springer: New York, NY, USA, 2013; ISBN 978-1-4614-8252-9.

5. Kosová, K.; Prášil, I.T.; Vítámvás, P.; Dobrev, P.; Motyka, V.; Floková, K.; Novák, O.; Turečková, V.; Rolčik, J.; Pešek, B.; et al. Complex phytohormone responses during the cold acclimation of two wheat cultivars differing in cold tolerance, winter Samanta and spring Sandra. J. Plant Physiol. 2012, 169, 567-576. [CrossRef] [PubMed]

6. Gusta, L.V.; Trischuk, R.; Weiser, C.J. Plant cold acclimation: The role of abscisic acid. J. Plant Growth Regul. 2005, 24, 308-318. [CrossRef]

7. Galiba, G.; Tuberosa, R.; Kocsy, G.; Sutka, J. Involvement of Chromosomes 5A and 5D in Cold-Induced Abscisic Acid Accumulation in and Frost Tolerance of Wheat Calli. Plant Breed. 1993, 110, 237-242. [CrossRef]

8. Vanková, R.; Kosová, K.; Dobrev, P.; Vítámvás, P.; Trávníčková, A.; Cvikrová, M.; Pešek, B.; Gaudinová, A.; Prerostová, S.; Musilová, J.; et al. Dynamics of cold acclimation and complex phytohormone responses in Triticum monococcum lines G3116 and DV92 differing in vernalization and frost tolerance level. Environ. Exp. Bot. 2014, 101, 12-25. [CrossRef]

9. Marin, E.; Nussaume, L.; Quesada, A.; Gonneau, M.; Sotta, B.; Hugueney, P.; Frey, A.; Marion-Poll, A. Molecular identification of zeaxanthin epoxidase of Nicotiana plumbaginifolia, a gene involved in abscisic acid biosynthesis and corresponding to the ABA locus of Arabidopsis thaliana. EMBO J. 1996, 15, 2331-2342. [CrossRef]

10. Seiler, C.; Harshavardhan, V.T.; Rajesh, K.; Reddy, P.S.; Strickert, M.; Rolletschek, H.; Scholz, U.; Wobus, U.; Sreenivasulu, N. ABA biosynthesis and degradation contributing to ABA homeostasis during barley seed development under control and terminal drought-stress conditions. J. Exp. Bot. 2011, 62, 2615-2632. [CrossRef]

11. Schwartz, S.H. Specific Oxidative Cleavage of Carotenoids by VP14 of Maize. Science 1997, 276, 1872-1874. [CrossRef]

12. Nambara, E.; Marion-Poll, A. Abscisic Acid Biosynthesis and Catabolism. Annu. Rev. Plant Biol. 2005, 56, 165-185. [CrossRef] [PubMed]

13. Lefebvre, V.; North, H.; Frey, A.; Sotta, B.; Seo, M.; Okamoto, M.; Nambara, E.; Marion-Poll, A. Functional analysis of Arabidopsis NCED6 and NCED9 genes indicates that ABA synthesized in the endosperm is involved in the induction of seed dormancy. Plant J. 2006, 45, 309-319. [CrossRef]

14. Kalapos, B.; Dobrev, P.; Nagy, T.; Vítámvás, P.; Györgyey, J.; Kocsy, G.; Marincs, F.; Galiba, G. Transcript and hormone analyses reveal the involvement of ABA-signalling, hormone crosstalk and genotype-specific biological processes in cold-shock response in wheat. Plant Sci. 2016, 253, 86-97. [CrossRef] 
15. Cheng, W.H.; Endo, A.; Zhou, L.; Penney, J.; Chen, H.C.; Arroyo, A.; Leon, P.; Nambara, E.; Asami, T.; Seo, M.; et al. A unique short-chain dehydrogenase/reductase in arabidopsis glucose signaling and abscisic acid biosynthesis and functions. Plant Cell 2002, 14, 2723-2743. [CrossRef]

16. González-Guzmán, A.M.; Apostolova, N.; Bellés, J.M.; Barrero, J.M.; Belles, J.M.; Barrero, J.M.; Piqueras, P.; Ponce, M.R.; Micoi, J.L.; Serrano, R.; et al. The Short-Chain Alcohol Dehydrogenase ABA2 Catalyzes the Conversion of Xanthoxin to Abscisic Aldehyde. Plant Cell 2012, 14, 1833-1846. [CrossRef] [PubMed]

17. Seo, M.; Aoki, H.; Koiwai, H.; Kamiya, Y.; Nambara, E.; Koshiba, T. Comparative studies on the Arabidopsis aldehyde oxidase (AAO) gene family revealed a major role of AAO3 in ABA biosynthesis in seeds. Plant Cell Physiol. 2004, 45, 1694-1703. [CrossRef] [PubMed]

18. Miura, K.; Tada, Y. Regulation of water, salinity, and cold stress responses by salicylic acid. Front. Plant Sci. 2014, 5, 1-12. [CrossRef] [PubMed]

19. Mutlu, S.; Karadağoğlu, Ö.; Atici, Ö.; Taşğin, E.; Nalbantoğlu, B. Time-dependent effect of salicylic acid on alleviating cold damage in two barley cultivars differing in cold tolerance. Turk. J. Bot. 2013, 37, 343-349.

20. Mutlu, S.; Karadağoğlu, Ö.; Atici, Ö.; Nalbantoğlu, B. Protective role of salicylic acid applied before cold stress on antioxidative system and protein patterns in barley apoplast. Biol. Plant 2013, 57, 507-513. [CrossRef]

21. Janda, T.; Szalai, G.; Tari, I.; Páldi, E. Hydroponic treatment with salicylic acid decreases the effects of chilling injury in maize (Zea mays L.) plants. Planta 1999, 208, 175-180. [CrossRef]

22. Horváth, E.; Janda, T.; Szalai, G.; Páldi, E. In vitro salicylic acid inhibition of catalase activity in maize: Differences between the isozymes and a possible role in the induction of chilling tolerance. Plant Sci. 2002, 163, 1129-1135. [CrossRef]

23. Yang, Y.; Qi, M.; Mei, C. Endogenous salicylic acid protects rice plants from oxidative damage caused by aging as well as biotic and abiotic stress. Plant J. 2004, 40, 909-919. [CrossRef] [PubMed]

24. Dempsey, D.A.; Vlot, A.C.; Wildermuth, M.C.; Klessig, D.F. Salicylic Acid Biosynthesis and Metabolism. Arab. B 2011, 9, e0156. [CrossRef]

25. Kim, D.S.; Hwang, B.K. An important role of the pepper phenylalanine ammonia-lyase gene (PAL1) in salicylic acid-dependent signalling of the defence response to microbial pathogens. J. Exp. Bot. 2014, 65, 2295-2306. [CrossRef]

26. Dixon, R.A.; Paiva, N.L. Stress-induced phenylpropanoid metabolism. Plant Cell 1995, 7, 1085-1097. [CrossRef] [PubMed]

27. Dong, C.; Li, L.; Cao, N.; Shang, Q.; Zhang, Z. Roles of phenylalanine ammonia-lyase in low temperature tolerance in cucumber seedlings. J. Appl. Ecol. 2015, 26, 2041-2049.

28. Gaudet, D.A.; Laroche, A.; Frick, M.; Davoren, J.; Puchalski, B.; Ergon, Å. Expression of plant defence-related (PR-protein) transcripts during hardening and dehardening of winter wheat. Physiol. Mol. Plant Pathol. 2000, 57, 15-24. [CrossRef]

29. Olenichenko, N.A.; Zagoskina, N.V. Response of winter wheat to cold: Production of phenolic compounds and L-phenylalanine ammonia-lyase activity. Prikl. Biokhimiia Mikrobiol. 2005, 41, 681-685. [CrossRef]

30. Avanci, N.C.; Luche, D.D.; Goldman, G.H.; Goldman, M.H. Jasmonates are phytohormones with multiple functions, including plant defense and reproduction. Genet. Mol. Res. 2010, 9, 484-505. [CrossRef] [PubMed]

31. Taniguchi, S.; Hosokawa-Shinonaga, Y.; Tamaoki, D.; Yamada, S.; Akimitsu, K.; Gomi, K. Jasmonate induction of the monoterpene linalool confers resistance to rice bacterial blight and its biosynthesis is regulated by JAZ protein in rice. Plant Cell Environ. 2014, 37, 451-461. [CrossRef]

32. Du, H.; Liu, H.; Xiong, L. Endogenous auxin and jasmonic acid levels are differentially modulated by abiotic stresses in rice. Front. Plant Sci. 2013, 4, 397. [CrossRef] [PubMed]

33. Djilianov, D.L.; Dobrev, P.I.; Moyankova, D.P.; Vankova, R.; Georgieva, D.T.; Gajdošová, S.; Motyka, V. Dynamics of Endogenous Phytohormones during Desiccation and Recovery of the Resurrection Plant Species Haberlea rhodopensis. J. Plant Growth Regul. 2013, 32, 564-574. [CrossRef]

34. Göbel, C.; Feussner, I. Methods for the analysis of oxylipins in plants. Phytochemistry 2009, 70, 1485-1503. [CrossRef]

35. Sharma, M.; Laxmi, A. Jasmonates: Emerging Players in Controlling Temperature Stress Tolerance. Front. Plant Sci. 2016, 6, 1129. [CrossRef]

36. Kazemi-Shahandashti, S.S.; Maali-Amiri, R.; Zeinali, H.; Khazaei, M.; Talei, A.; Ramezanpour, S.S. Effect of short-term cold stress on oxidative damage and transcript accumulation of defense-related genes in chickpea seedlings. J. Plant Physiol. 2014, 171, 1106-1116. [CrossRef] [PubMed]

37. Copolovici, L.; Kännaste, A.; Pazouki, L.; Niinemets, Ü. Emissions of green leaf volatiles and terpenoids from Solanum lycopersicum are quantitatively related to the severity of cold and heat shock treatments. J. Plant Physiol. 2012, 169, 664-672. [CrossRef] [PubMed]

38. Hannah, M.A.; Heyer, A.G.; Hincha, D.K. A global survey of gene regulation during cold acclimation in Arabidopsis thaliana. PLoS Genet. 2005, 1, e26. [CrossRef] [PubMed]

39. Jain, M.; Khurana, J.P. Transcript profiling reveals diverse roles of auxin-responsive genes during reproductive development and abiotic stress in rice. FEBS J. 2009, 276, 3148-3162. [CrossRef] [PubMed]

40. Eremina, M.; Rozhon, W.; Poppenberger, B. Hormonal control of cold stress responses in plants. Cell. Mol. Life Sci. 2016, 73, 797-810. [CrossRef] [PubMed]

41. González-Lamothe, R.; El Oirdi, M.; Brisson, N.; Bouarab, K. The conjugated auxin indole-3-acetic acid-aspartic acid promotes plant disease development. Plant Cell 2012, 24, 672-777. [CrossRef] 
42. Weijers, D.; Nemhauser, J.; Yang, Z. Auxin: Small molecule, big impact. J. Exp. Bot. 2018, 69, 133-136. [CrossRef]

43. Zhao, Y. Auxin Biosynthesis. Arab. B 2014, 12, e0173. [CrossRef]

44. Ryu, H.; Cho, Y.G. Plant hormones in salt stress tolerance. J. Plant Biol. 2015, 58, 147-155. [CrossRef]

45. Prerostova, S.; Černý, M.; Dobrev, P.I.; Motyka, V.; Hluskova, L.; Zupkova, B.; Gaudinova, A.; Knirsch, V.; Janda, T.; Brzobohatý, B.; et al. Light Regulates the Cytokinin-Dependent Cold Stress Responses in Arabidopsis. Front. Plant Sci. 2021, $11,608711$. [CrossRef] [PubMed]

46. Argueso, C.T.; Ferreira, F.J.; Kieber, J.J. Environmental perception avenues: The interaction of cytokinin and environmental response pathways. Plant Cell Environ. 2009, 32, 1147-1160. [CrossRef]

47. Gajdošová, S.; Spíchal, L.; Kamínek, M.; Hoyerová, K.; Novák, O.; Dobrev, P.I.; Galuszka, P.; Klíma, P.; Gaudinová, A.; Žižková, E.; et al. Distribution, biological activities, metabolism, and the conceivable function of cis-zeatin-type cytokinins in plants. J. Exp. Bot. 2011, 62, 2827-2840. [CrossRef] [PubMed]

48. Sakakibara, H. CYTOKININS: Activity, Biosynthesis, and Translocation. Annu. Rev. Plant Biol. 2006, 57, 431-449. [CrossRef] [PubMed]

49. Schäfer, M.; Brütting, C.; Meza-Canales, I.D.; Großkinsky, D.K.; Vankova, R.; Baldwin, I.T.; Meldau, S. The role of cis-zeatin-type cytokinins in plant growth regulation and mediating responses to environmental interactions. J. Exp. Bot. 2015, 66, 4873-4884. [CrossRef] [PubMed]

50. Alabadí, D.; Blázquez, M.A. Molecular interactions between light and hormone signaling to control plant growth. Plant Mol. Biol. 2009, 69, 409-417. [CrossRef] [PubMed]

51. Lau, O.S.; Deng, X.W. Plant hormone signaling lightens up: Integrators of light and hormones. Curr. Opin. Plant Biol. 2010, 13, 571-577. [CrossRef] [PubMed]

52. Franklin, K.A.; Whitelam, G.C. Phytochromes and shade-avoidance responses in plants. Ann. Bot. 2005, 96, 169-175. [CrossRef] [PubMed]

53. Zhou, Y.; Zhang, D.; An, J.; Yin, H.; Fang, S.; Chu, J.; Zhao, Y.; Li, J. TCP transcription factors regulate shade avoidance via directly mediating the expression of both Phytochrome Interacting Factors and auxin biosynthetic genes. Plant Physiol. 2018, 176, 1850-1861. [CrossRef]

54. Carabelli, M.; Possenti, M.; Sessa, G.; Ciolfi, A.; Sassi, M.; Morelli, G.; Ruberti, I. Canopy shade causes a rapid and transient arrest in leaf development through auxin-induced cytokinin oxidase activity. Genes Dev. 2007, 21, 1863-1868. [CrossRef]

55. Zhang, R.; Zhang, X.; Wang, J.; Letham, D.S.; McKinney, S.A.; Higgins, T.J.V. The effect of auxin on cytokinin levels and metabolism in transgenic tobacco tissue expressing an ipt gene. Planta 1995, 196, 84-94. [CrossRef]

56. Moreno, J.E.; Tao, Y.; Chory, J.; Ballaré, C.L. Ecological modulation of plant defense via phytochrome control of jasmonate sensitivity. Proc. Natl. Acad. Sci. USA 2009, 106, 4935-4940. [CrossRef] [PubMed]

57. Yang, C.; Li, L. Hormonal regulation in shade avoidance. Front. Plant Sci. 2017, 8, 1527. [CrossRef] [PubMed]

58. Holmes, M.G.; Smith, H. the Function of Phytochrome in the Natural Environment-I. Characterization of Daylight for Studies in Photomorphogenesis and Photoperiodism. Photochem. Photobiol. 1977, 25, 533-538. [CrossRef]

59. Linkosalo, T.; Lechowicz, M.J. Twilight far-red treatment advances leaf bud burst of silver birch (Betula pendula). Tree Physiol. 2006, 26, 1249-1256. [CrossRef]

60. Olsen, J.E.; Junttila, O. Far red end-of-day treatment restores wild type-like plant length in hybrid aspen overexpressing phytochrome A. Physiol. Plant 2002, 115, 448-457. [CrossRef]

61. Novák, A.; Boldizsár, Á.; Ádám, É.; Kozma-Bognár, L.; Majláth, I.; Båga, M.; Tóth, B.; Chibbar, R.; Galiba, G. Light-quality and temperature-dependent CBF14 gene expression modulates freezing tolerance in cereals. J. Exp. Bot. 2016, 67, 1285-1295. [CrossRef]

62. Ahres, M.; Gierczik, K.; Boldizsár, Á.; Vítámvás, P.; Galiba, G. Temperature and light-quality-dependent regulation of freezing tolerance in barley. Plants 2020, 9, 83. [CrossRef] [PubMed]

63. Franklin, K.A.; Whitelam, G.C. Light-quality regulation of freezing tolerance in Arabidopsis thaliana. Nat. Genet. 2007, 39, 1410-1413. [CrossRef] [PubMed]

64. Franklin, K.A.; Quail, P.H. Phytochrome functions in Arabidopsis development. J. Exp. Bot. 2010, 61, 11-24. [CrossRef] [PubMed]

65. Gierczik, K.; Novák, A.; Ahres, M.; Székely, A.; Soltész, A.; Boldizsár, Á.; Gulyás, Z.; Kalapos, B.; Monostori, I.; Kozma-Bognár, L.; et al. Circadian and light regulated expression of CBFs and their upstream signalling genes in barley. Int. J. Mol. Sci. 2017, 18, 1828. [CrossRef] [PubMed]

66. Jiang, B.; Shi, Y.; Peng, Y.; Jia, Y.; Yan, Y.; Dong, X.; Li, H.; Dong, J.; Li, J.; Gong, Z.; et al. Cold-Induced CBF-PIF3 Interaction Enhances Freezing Tolerance by Stabilizing the phyB Thermosensor in Arabidopsis. Mol. Plant 2020, 13, 894-906. [CrossRef] [PubMed]

67. Wang, F.; Guo, Z.; Li, H.; Wang, M.; Onac, E.; Zhou, J.; Xia, X.; Shi, K.; Yu, J.; Zhou, Y. Phytochrome a and b function antagonistically to regulate cold tolerance via abscisic acid-dependent jasmonate signaling 1. Plant Physiol. 2016, 170, 459-471. [CrossRef] [PubMed]

68. Kovács, T.; Ahres, M.; Pálmai, T.; Kovács, L.; Uemura, M.; Crosatti, C.; Galiba, G. Decreased r:Fr ratio in incident white light affects the composition of barley leaf lipidome and freezing tolerance in a temperature-dependent manner. Int. J. Mol. Sci. 2020, 21, 7557. [CrossRef] [PubMed]

69. Zadoks, J.C.; Board, E. Data sheet highlights close coupled pumps. World Pumps 1999, 1999, 9. 
70. Webb, M.S.; Uemura, M.; Steponkus, P.L. A comparison of freezing injury in oat and rye: Two cereals at the extremes of freezing tolerance. Plant Physiol. 1994, 104, 467-478. [CrossRef]

71. Ivanov Dobrev, P.; Kamínek, M. Fast and efficient separation of cytokinins from auxin and abscisic acid and their purification using mixed-mode solid-phase extraction. J. Chromatogr. A 2002, 950, 21-29. [CrossRef]

72. Dobrev, P.I.; Vankova, R. Quantification of abscisic acid, cytokinin, and auxin content in salt-stressed plant tissues. Methods Mol. Biol. 2012, 913, 251-261.

73. Livak, K.J.; Schmittgen, T.D. Analysis of relative gene expression data using real-time quantitative PCR and the 2- $\Delta \Delta C T$ method. Methods 2001, 25, 402-408. [CrossRef] [PubMed]

74. Gururani, M.A.; Venkatesh, J.; Ganesan, M.; Strasser, R.J.; Han, Y.; Kim, J.-I.; Lee, H.Y.; Song, P.S. In Vivo assessment of cold tolerance through chlorophyll-a fluorescence in transgenic zoysiagrass expressing mutant phytochrome A. PLoS ONE 2015, 10, e0127200. [CrossRef]

75. Ganesan, M.; Han, Y.J.; Bae, T.W.; Hwang, O.J.; Chandrasekhar, T.; Shin, A.Y.; Goh, C.H.; Nishiguchi, S.; Song, I.J.; Lee, H.Y.; et al. Overexpression of phytochrome A and its hyperactive mutant improves shade tolerance and turf quality in creeping bentgrass and zoysiagrass. Planta 2012, 236, 1135-1150. [CrossRef]

76. Klem, K.; Gargallo-Garriga, A.; Rattanapichai, W.; Oravec, M.; Holub, P.; Veselá, B.; Sardans, J.; Peñuelas, J.; Urban, O. Distinct Morphological, Physiological, and Biochemical Responses to Light Quality in Barley Leaves and Roots. Front. Plant Sci. 2019, 10, 1026. [CrossRef] [PubMed]

77. Ballaré, C.L.; Pierik, R. The shade-avoidance syndrome: Multiple signals and ecological consequences. Plant Cell Environ. 2017, 40, 2530-2543. [CrossRef] [PubMed]

78. Panigrahy, M.; Majeed, N.; Panigrahi, K.C.S. Low-light and its effects on crop yield: Genetic and genomic implications. J. Biosci. 2020, 45, 102. [CrossRef]

79. Xu, D.; Li, J.; Gangappa, S.N.; Hettiarachchi, C.; Lin, F.; Andersson, M.X.; Jiang, Y.; Deng, X.W.; Holm, M. Convergence of Light and ABA Signaling on the ABI5 Promoter. PLoS Genet. 2014, 10, e1004197. [CrossRef]

80. Seo, M.; Nambara, E.; Choi, G.; Yamaguchi, S. Interaction of light and hormone signals in germinating seeds. Plant Mol. Biol. 2009, 69, 463-472. [CrossRef]

81. Reddy, S.K.; Holalu, S.V.; Casal, J.J.; Finlayson, S.A. Abscisic acid regulates axillary bud outgrowth responses to the ratio of red to far-red light. Plant Physiol. 2013, 163, 1047-1058. [CrossRef] [PubMed]

82. Francis, D.; Sorrell, D.A. The interface between the cell cycle and plant growth regulators: A mini review. Plant Growth Regul. 2001, 33, 1-12. [CrossRef]

83. Voitsekhovskaja, O.V. Phytochromes and Other (Photo)Receptors of Information in Plants. Russ. J. Plant Physiol. 2019, 66, 351-364. [CrossRef]

84. Leone, M.; Keller, M.M.; Cerrudo, I.; Ballaré, C.L. To grow or defend? Low red: Far-red ratios reduce jasmonate sensitivity in Arabidopsis seedlings by promoting DELLA degradation and increasing JAZ10 stability. New Phytol. 2014, 204, 355-367. [CrossRef] [PubMed]

85. Ballaré, C.L. Light Regulation of Plant Defense. Annu. Rev. Plant Biol. 2014, 65, 335-363. [CrossRef] [PubMed]

86. De Wit, M.; Spoel, S.H.; Sanchez-Perez, G.F.; Gommers, C.M.M.; Pieterse, C.M.J.; Voesenek, L.A.C.J.; Pierik, R. Perception of low red: Far-red ratio compromises both salicylic acid- and jasmonic acid-dependent pathogen defences in Arabidopsis. Plant J. 2013, 75, 90-103. [CrossRef]

87. Kohnen, M.V.; Schmid-Siegert, E.; Trevisan, M.; Petrolati, L.A.; Sénéchal, F.; Müller-Moulé, P.; Maloof, J.; Xenarios, I.; Fankhauser, C. Neighbor detection induces organ-specific transcriptomes, revealing patterns underlying hypocotyl-specific growth. Plant Cell 2016, 28, 2889-2904. [CrossRef]

88. Ma, L.; Li, G. Auxin-dependent cell elongation during the shade avoidance response. Front. Plant Sci. 2019, 10, 914. [CrossRef]

89. Eklöf, S.; Åstot, C.; Blackwell, J.; Moritz, T.; Olsson, O.; Sandberg, G. Auxin-cytokinin interactions in wild-type and transgenic tobacco. Plant Cell Physiol. 1997, 38, 225-235. [CrossRef]

90. Kurepin, L.V.; Emery, R.J.N.; Pharis, R.P.; Reid, D.M. The interaction of light quality and irradiance with gibberellins, cytokinins and auxin in regulating growth of Helianthus annuus hypocotyls. Plant Cell Environ. 2007, 30, 147-155. [CrossRef] [PubMed]

91. Kalapos, B.; Novák, A.; Dobrev, P.; Vítámvás, P.; Marincs, F.; Galiba, G.; Vanková, R. Effect of the winter wheat cheyenne 5A substituted chromosome on dynamics of abscisic acid and cytokinins in freezing-sensitive Chinese spring genetic background. Front. Plant Sci. 2017, 8, 2033. [CrossRef]

92. Tuteja, N. Abscisic acid and abiotic stress signaling. Plant Signal. Behav. 2007, 2, 135-138. [CrossRef]

93. Hu, Y.; Jiang, Y.; Han, X.; Wang, H.; Pan, J.; Yu, D. Jasmonate regulates leaf senescence and tolerance to cold stress: Crosstalk with other phytohormones. J. Exp. Bot. 2017, 68, 1361-1369. [CrossRef] [PubMed]

94. Monostori, I.; Heilmann, M.; Kocsy, G.; Rakszegi, M.; Ahres, M.; Altenbach, S.B.; Szalai, G.; Pál, M.; Toldi, D.; Simon-Sarkadi, L.; et al. LED lighting-Modification of growth, metabolism, yield and flour composition in wheat by spectral quality and intensity. Front. Plant Sci. 2018, 9, 605. [CrossRef] [PubMed]

95. Watson, A.; Ghosh, S.; Williams, M.J.; Cuddy, W.S.; Simmonds, J.; Rey, M.D.; Asyraf Md Hatta, M.; Hinchliffe, A.; Steed, A.; Reynolds, D.; et al. Speed breeding is a powerful tool to accelerate crop research and breeding. Nat. Plants 2018, 4, 23-29. [CrossRef] 
96. Monteagudo, A.; Kiss, T.; Mayer, M.; Casas, A.M.; Igartua, E.; Karsai, I. Genetic diversity in developmental responses to light spectral quality in barley (Hordeum vulgare L.). BMC Plant Biol. 2020, 20, 207. [CrossRef]

97. Pociecha, E.; Płazek, A.; Janowiak, F.; Zwierzykowski, Z. ABA level, proline and phenolic concentration, and PAL activity induced during cold acclimation in androgenic Festulolium forms with contrasting resistance to frost and pink snow mould (Microdochium nivale). Physiol. Mol. Plant Pathol. 2008, 73, 126-132. [CrossRef]

98. Hura, K.; Hura, T.; Rapacz, M.; Płazek, A. Effects of low-temperature hardening on the biochemical response of winter oilseed rape seedlings inoculated with the spores of Leptosphaeria maculans. Biology 2015, 70, 1011-1018. [CrossRef]

99. Liu, J.Y.; Zhang, C.; Shao, Q.; Tang, Y.F.; Cao, S.X.; Guo, X.O.; Jin, Y.Z.; Qi, H.Y. Effects of abiotic stress and hormones on the expressions of five 13-CmLOXs and enzyme activity in oriental melon (Cucumis melo var. makuwa Makino). J. Integr. Agric. 2016, 15, 326-338. [CrossRef]

100. Bravo, L.A.; Zuniga, G.E.; Alberdi, M.; Corcuera, L.J. The role of ABA in freezing tolerance and cold acclimation in barley. Physiol. Plant 1998, 103, 17-23. [CrossRef] 